\title{
SUKUK SEBAGAI ALTERNATIF INSTRUMEN INVESTASI DAN PENDANAAN
}

\author{
Ika Indriasari \\ Universitas PGRI, Semarang \\ (ika.antono@gmail.com)
}

\begin{abstract}
Sukuk is a form of Islamic investment instrument that is developing in Indonesia and various countries in the world. The superiority of Sukuk as a form of relatively safe investment makes sukuk accepted as an investment tool as well as funding for countries with a majority of Muslim and non-Muslim populations. The Indonesian government began to establish rules regarding sukuk since 2008 and continues to develop and innovate in sukuk transactions. Greetings and interest in investing in Indonesian sukuk are very good, both in the domestic and global markets. This can be seen from the oversubscription that occurs in Indonesian sukuk. Great interest in sukuk, especially in Indonesia shows that sukuk can provide good alternatives for investors and the country for funding needs in Indonesia's development.
\end{abstract}

Keywords: sukuk, investment, and funding

\section{A. Pendahuluan}

Sistem ekonomi syariah merupakan salah satu sistem perekonomian yang sedang berkembang dengan cukup pesat, baik di Indonesia maupun di mancanegara. Keunggulan dan manfaat yang dirasakan pada perekonomian syariah mendorong bekembangnya sistem ekonomi ini, baik di negara yang banyak penduduk muslimnya seperti Bahrain, Qatar, Saudi Arabia, Malaysia, dan Indonesia, maupun diantara negara yang notabene penduduk terbesarnya adalah non muslim seperti Inggris, Jepang, Hongkong, Singapore dan Korea Selatan. 
Dalam perkembangan sistem ekonomi syariah di Indonesia, salah satu lembaga keuangan yang juga ikut berkembang adalah pasar modal. Pasar modal yang selama ini merepresentasikan transaksi jual-beli efek, seperti: saham, obligasi, reksadana, dan derivatif, kini mulai dimarakkan oleh transaksi produk keuangan baru berbasis syariah. Salah satu produk tersebut adalah obligasi syariah atau yang sering disebut sukuk. (Abdul Wahid, 2010:92).

Sukuk adalah bahasa Arab bentuk jamak yang artinya sertifikat. Sukuk dalam pasar modal Islam (Islamic Capital Market) serupa dengan obligasi yang terdapat di pasar modal konvensional, yaitu surat atau sertifikat dari pihak yang membutuhkan dana. Perbedaannya adalah obligasi merupakan surat hutang, sedangkan sukuk lebih merupakan sertifikat kepemilikan kepentingan dalam suatu aset. Obligasi mewajibkan pihak yang berhutang untuk membayarkan bunga atau kupon kepada pihak yang memberikan hutang. Praktek bunga seperti ini jelas tidak dibenarkan secara syariah, karena mengandung unsur riba (Siskawati, 2010). Sukuk dalam hal ini dapat menjawab salah satu kebutuhan instrumen keuangan yang halal, yang bagi umat muslim pada khususnya adalah sebuah kebutuhan yang mendesak.

Sukuk seringkali disebut obligasi Islami, namun ada perbedaan yang cukup mendasar antara sukuk dengan obligasi. The Accounting and Auditing Organization for Islamic Financial Institution (AAOIFI) dalam standar no 17 mendefinisikan sukuk sebagai:

"insvestment sukuk are certificates of equal value representing undivided shares in ownership of tangible assets usufruct and services (in the ownership of) the assets or particular projects or special investment activity, however, this is true after receipt of the value of the sukuk, the closing of subscription and the employment of funds received for the purpose for which the sukuk were issued."

Bapepam LK dalam peraturan No.IX.A.14, mendefinisikan sukuk sebagai: "efek syariah berupa sertifikat atau bukti kepemilikan yang bernilai sama dan mewakili bagian penyertaan yang tidak terpisahkan atau tidak terbagi atas: 1 . Kepemilikan aset berwujud tertentu 2. Nilai manfaat dan jasa atas aset proyek tertentu atau aktivitas investasi 
tertentu; atau 3. Kepemilikan atas aset proyek tertentu atau aktivitas investasi tertentu"

Meskipun sukuk disebut sebagai obligasi syariah, namun pada prinsipnya sukuk lebih menekankan pada kontrak jual beli (Siskawati, 2010). Sukuk juga bukan hanya sekedar surat hutang seperti obligasi pada umumnya. Namun sukuk merupakan surat hutang yang berbasiskan pada hukum syariah sebagai aturan atau pedoman batasanbatasannya dan berbasiskan pada aset perusahaan yang berwujud (tangible asset) sebagai penjamin dari sukuk tersebut. Investasi pada sukuk juga memperhatikan keuntungan bagi investornya serta menjamin keuntungan investor sebagai pihak pemberi pinjaman. Dalam hal ini dapat dikatakan bahwa sukuk merupakan instrumen investasi yang relatif aman. Sukuk disebut aman karena merupakan instrumen investasi yang berbasiskan pada kegiatan atau proyek yang produktif, bukan spekulatif, sehingga risiko investasi yang dihadapi adalah risiko karena proyek yang dijadikan jaminan tersebut, bukan risiko karena spekulatif (Mersilia, 2014)

Keberadaan sukuk saat ini dapat dikatakan tidak bisa dipisahkan lagi dengan sistem keuangan global (Sunarsip, 2008). Minat investor terhadap sukuk juga tergolong besar terkait dengan sifat sukuk yang relatif aman dan menguntungkan. Mengingat bahwa jaminan sukuk adalah proyek-proyek produktif, maka sukuk juga memiliki fungsi sebagai sumber pendanaan bagi berbagai proyek pemerintah maupun proyek swasta. Dalam hal ini, adanya sukuk dapat berperan sebagai produk investasi, baik bagi perorangan maupun badan sekaligus sebagai solusi alternatif bagi pendanaan berbagai proyek.

\section{B. Landasan Teori}

1) Pengertian Sukuk

Tim studi pasar modal Bapepam-LK (2009) telah merumuskan bahwa pada dasarnya definisi sukuk yang berasal dari berbagai sumber literatur dapat dibagi menjadi dua, yaitu definisi secara etimologi dan definisi secara terminologi. Secara etimologi (bahasa) sukuk berasal dari bentuk jamak bahasa Arab "sakk" yang berarti sertifikat, perjanjian atau instrumen hukum. Secara terminologi, sukuk 
dapat didefinisikan sebagai sertifikat kepercayaan atas kepemilikan sesuatu, dengan masing-masing sakk menunjukkan kepentingan kepemilikan yang proporsional dan tidak dapat dipisahkan dalam suatu aset atau kumpulan aset.

DSN MUI dalam fatwa DSN MUI No. 32/ DN-MUI/ IX/2002 mendefinisikan obligasi syariah/ sukuk sebagai berikut:

"...suatu surat berharga jangka panjang berdasarkan syariah yang dikeluarkan oleh emiten kepada pemegang obligasi syariah yang mewajibkan emiten untuk membayar pendapatan kepada pemegang obligasi syariah berupa bagi hasil/ margin/ fee serta membayar kembali dana obligasi pada saat jatuh tempo"

Selanjutnya menurut Bapepam LK dalam peraturan No IX. A.13 tentang Penerbitan Efek Syariah, sukuk didefinisikan sebagai berikut: Efek Syariah berupa sertifikat atau bukti kepemilikan yang bernilai sama dan mewakili bagian yang tidak tertentu (tidak terpisahkan atau tidak terbagi (syuyu' atau undevided share) atas:

a) Aset berwujud tertentu ( $a^{\prime}$ yan maujudat);

b) Nilai manfaat atas aset berwujud (a'yan maujudat);

c) Jasa (al khadamat) yang sudah ada maupun yang akan ada;

d) Aset proyek tertentu (maujudat masyru' mu'ayyan); dan /atau

e) Kegiatan investasi yang telah ditentukan (nasyath istismarin khashah)

Dalam pengertian secara teknis, sukuk adalah surat hutang yang diterbitkan oleh pemerintah atau perusahaan sebagai tambahan dana bagi penerbit dari pihak masyarakat sebagai investor. Para investor berhak atas keuntungan, kepemilikan atas aset tertentu, manfaat, jasa, dan atau proyek penerbit. (Mersilia, 2014). Menurut AAOIFI (dalam Abdul Wahid, Nazaruddin: 2010), “Terdapat pembeda antara investasi sukuk dengan shares, notes, dan bonds, meskipun semua itu berhubungan dengan kontrak peralihan hutang dalam bentuk uang dan aset.

Pada dasarnya sukuk adalah suatu bentuk sekuritisasi aset. Berbeda dengan obligasi konvensional, di dalam transaksi sukuk harus dilandasi oleh aset yang berwujud (tangible asset). Pendapatan yang diperoleh dari sukuk ini pun berasal dari pemanfaatan dana yang tepat dan dijamin oleh aset yang riil (Nurkholis, 2011). Di dalam sukuk, underlying aset dibutuhkan sebagai jaminan bahwa penerbitan sukuk didasarkan nilai yang sama dengan aset yang tersedia. Oleh karenanya, aset harus memiliki nilai ekonomis, baik berupa aset 
berwujud atau tidak berwujud, termasuk proyek yang akan atau sedang dibangun. Adapun fungsi underlying asset tersebut adalah: (i) untuk menghindari riba, (ii) sebagai prasyarat untuk dapat diperdagangkannya sukuk di pasar sekunder, dan (iii) akan menentukan jenis struktur sukuk. Dalam sukuk ijarah al muntahiya bittamlik atau ijarah-sale and lease back, penjualan aset tidak disertai penyerahan fisik aset tetapi yang dialihkan adalah hak manfaat (beneficial title) sedangkan kepemilikan aset (legal title) tetap pada obligor. Pada akhir periode sukuk, SPV (Special Purpose Vehicle) wajib menjual kembali aset tersebut kepada obligor. (Nurkholis, 2011)

Pada sukuk ditentukan pula batas-batas standar sebagai instrumen dengan nilai intrinsik, sedangkan shares, notes, dan bonds lebih mengutamakan pada transfer jaminan finansial." Secara keseluruhan sukuk merupakan surat hutang Islam yang tidak hanya berkaitan dengan pemindahan finansial atau modal dari para investor ke penerbit, tetapi juga pemindahan aset atau manfaat atas aset tersebut dari penerbit kepada para investor. Berdasarkan penerbitnya, ada 3 jenis sukuk, yaitu (Mersilia, 2014):

a) Sukuk pemerintah atau sukuk negara (sovereign sukuk), ialah surat hutang syariah yang diterbitkan oleh negara untuk keperluan membiayai APBN negara atau proyek-proyek negara, seperti pembangunan infrastruktur.

b) Sukuk korporasi, ialah surat hutang syariah yang diterbitkan oleh perusahaan atau emiten untuk keperluan membiayai kebutuhan dana perusahaan atau proyek-proyek perusahaan.

c) Sukuk global, ialah surat hutang syariah yang diterbitkan oleh negara-negara lain secara internasional.

Dalam AAOIFI Sharia Standars Nomor 17, pembagian jenis sukuk dapat diklasifikasikan ke dalam 14 (empat belas) jenis sukuk berdasarkan akad dan underlying asset yang digunakan. Masingmasing jenis sukuk tersebut memiliki ketentuan syariah tersendiri, baik dalam hal penerbitan maupun perdagangannya di pasar sekunder. Dalam praktiknya di industri keuangan syariah keempat belas jenis sukuk tersebut dapat digolongkan ke dalam tiga kelompok, yaitu:

a) Sukuk berbasis akad Ijarah (Ijarah Based Sukuk), yang terdiri dari lima jenis sukuk;

b) Sukuk berbasis akad jual beli (Sale Based Sukuk), yang terdiri dari tiga jenis sukuk; 
c) Sukuk berbasis akad kerjasama (Participation Based Sukuk), yang terdiri dari enam jenis sukuk.

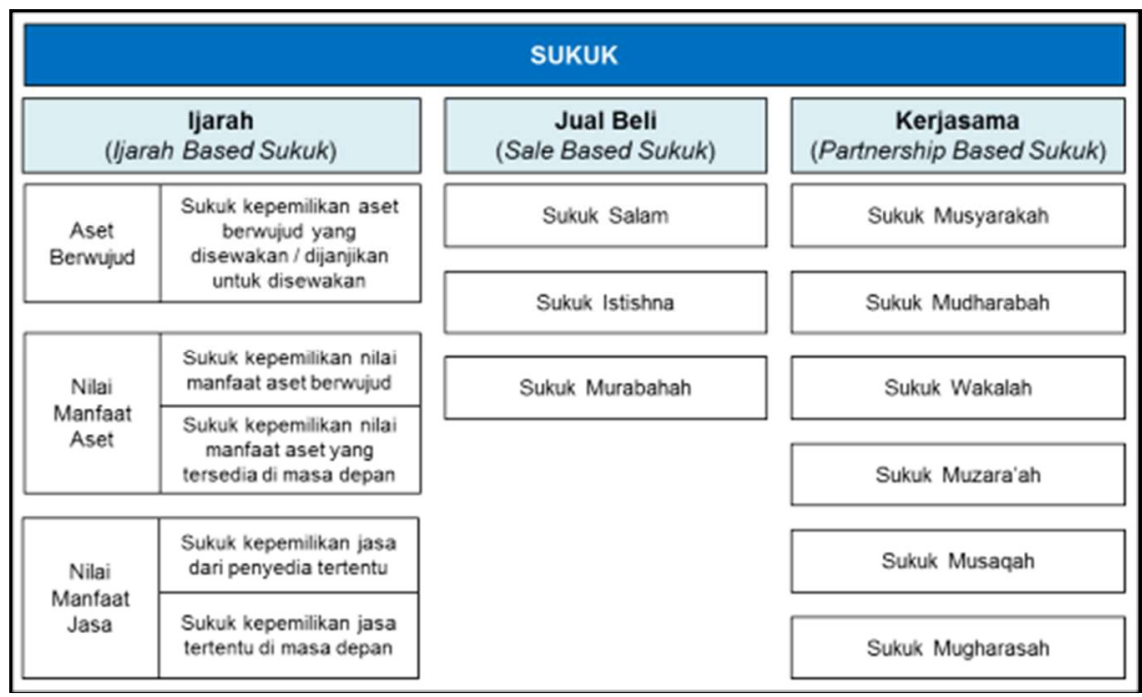

Gambar 1. Jenis-Jenis Sukuk

Di Indonesia, jenis sukuk berdasarkan akad yang mendasari penerbitan sukuk tersebut. Menurut fatwa DSN-MUI nomor 32/DSNMUI/IX/2002, terdapat 6 akad sukuk yang berlaku di Indonesia, yaitu : Sukuk ijarah, Sukuk Salam, Sukuk Istishna', Sukuk Murabahah, Sukuk Mudharabah, dan Sukuk Musyarakah. Masing-masing akad tersebut menggambarkan

\section{2) Sukuk Sebagai instrumen pembiayaan}

Sukuk pada awal kemunculannya merupakan produk yang digunakan secara luas pada abad pertengahan Islam untuk mentransfer kewajiban keuangan yang berasal dari perdagangan dan kegiatan komersial lainnya. Sukuk berasal dari bentuk jamak dalam bahasa Arab yakni 'sak' bermakna akta atau sertifikat kepemilikan. Sumber lain menyebutkan, kata tersebut kemudian menjadi asal dari kata 'cheque' dalam bahasa Eropa yang berarti sebuah dokumen yang merepresentasikan sebuah kontrak (contracts) atau pengalihan kepemilikan (conveyance of rights), obligasi (obligations) atau kewajiban yang harus dipenuhi (monies done) berdasarkan prinsip syari'ah (Rifki dan Musari, 2009). Sejalan dengan pesatnya penerbitan obligasi konvensional yang berbasis bunga pada abad ke-19, para cendekiawan 
syariah mulai berupaya mengembangkan alternatif dari instrumen sejenis yang berbasis syariah. Dimulai dari Yordania pada tahun 1978, disusul oleh Pakistan dan Malaysia pada tahun 1980-an.

Penerbitan obligasi Islam yang pertama kali sukses adalah Government Investment Issues (GII) sebelumnya dikenal dengan Government Investment Certificate (GIC) yang dilakukan oleh pemerintah Malaysia pada 1983. Namun, langkah inovasi yang ada lamban dan institusi finansial Islam saat itu tidak dapat mengembangkan pasar aktif bagi sekuritas tersebut. Berikutnya, kesuksesan sekuritisasi aset dalam pasar konvensional menghadirkan kerangka yang justru dapat diaplikasikan untuk aset Islam. Pada akhir 1990, struktur berbasis aset yang cukup diakui dalam bentuk sukuk dikembangkan di Bahrain dan Malaysia. Struktur ini menarik perhatian investor dan peminjam karena dianggap kendaraan potensial untuk mengembangkan pasar kapital Islam (Iqbal dan Mirakhor, 2008). Penerbitan sukuk yang berbasis sekuritisasi aset dilakukan pertama kali di Malaysia. Pada tahun 1990, Shell MDS menerbitkan sukuk korporasi pertama dengan struktur Bai' Bithaman Ajil. Selanjutnya menyusul di Bahrain, penerbitan sukuk dimulai pada bulan Juni 2001.

Pada tahun 2002, pemerintah Malaysia menerbitkan Global Sovereign Sukuk pertama kalinya dengan struktur sukuk Ijarah senilai USD 600 juta. Penerbitan dan pengembangan sukuk tersebut didukung oleh landasan syariah berupa fatwa yang memberikan pedoman dalam rangka penerbitan sukuk. Fatwa tersebut antara lain dikeluarkan oleh Islamic Jurisprudence Council pada tahun 2001, yang dianggap sebagai tonggak sejarah penting yang mendukung perkembangan sukuk. (Pridityo, 2014).

Saat ini sukuk tidak hanya diterbitkan oleh korporasi (corporate sukuk), namun sukuk telah banyak diterbitkan oleh negara (sovereign sukuk). Bahkan penerbitan sovereign sukuk ini menjadi pendorong utama perkembangan pasar sukuk internasional. Sukuk juga diadopsi secara luas baik di negara yang berpenduduk mayoritas muslim maupun nonmuslim. Negara-negara seperti Indonesia, Malaysia, Brunei Darussalam, Pakistan, Qatar, Bahrain, Saxony Anhalt (negara bagian Jerman), Uni Arab Emirates, Sudan, Gambia, Singapura, China, Jepang telah menerbitkan sukuk, dan diantaranya menerbitkan sukuk secara reguler baik di pasar domestik maupun internasional. Pada tahun 2014 lalu, Inggris dan Hongkong bahkan telah menerbitkan sukuk perdananya. Luksemburg dan Afrika Selatan juga menyusul menerbitkan sukuk pada 
tahun tersebut. Penerimaan terhadap sukuk dari berbagai negara merupakan indikasi bahwa sukuk telah berkembang menjadi instrumen pembiayaan dan investasi berbasis syariah yang diterima secara universal. Manfaat sukuk diakui tidak terbatas pada suatu golongan atau bahkan agama tertentu saja. Di sisi lain, hal ini juga memberikan bukti bahwa syariah memiliki fleksibilitas yang sangat tinggi, dan dapat diterapkan pada semua aspek kehidupan manusia termasuk aspek ekonomi dan keuangan.

Di Indonesia, perkembangan sukuk bermula karena adanya inisiatif dari swasta pada tahun 2002. Dibandingkan dengan negaranegara yang mayoritas penduduknya adalah muslim, munculnya sukuk di Indonesia tergolong lambat. PT Indosat Tbk adalah perusahaan pertama yang menerbitkan sukuk korporat senilai 175 miliar rupiah dengan menggunakan akad mudharabah (Siskawati, 2010). Sejak bulan Juni 2006, pemerintah Indonesia mulai bekerja keras menyusun draf RUU tentang Surat Berharga Syariah Negara (SBSN).

RUU tersebut disahkan menjadi Undang-Undang pada tanggal 7 Mei 2008 dan diundangkan dalam Lembaran Negara Republik Indonesia Tahun 2008 Nomor 70. Undang-Undang ini menjadi tonggak awal sejarah perkembangan Sukuk Negara di Indonesia dan juga di dunia. UndangUndang tersebut memberi landasan hukum penerbitan Sukuk Negara oleh Pemerintah Pusat sekaligus memberi koridor hukum pengelolaannya yang transparan dan akuntabel. Di samping itu bagi investor, Undang-Undang tersebut dipandang dapat memberi kepastian hukum antara lain berupa jaminan pembayaran nilai nominal dan imbalan, termasuk jaminan dari aspek syariahnya (Pridityo, 2014)

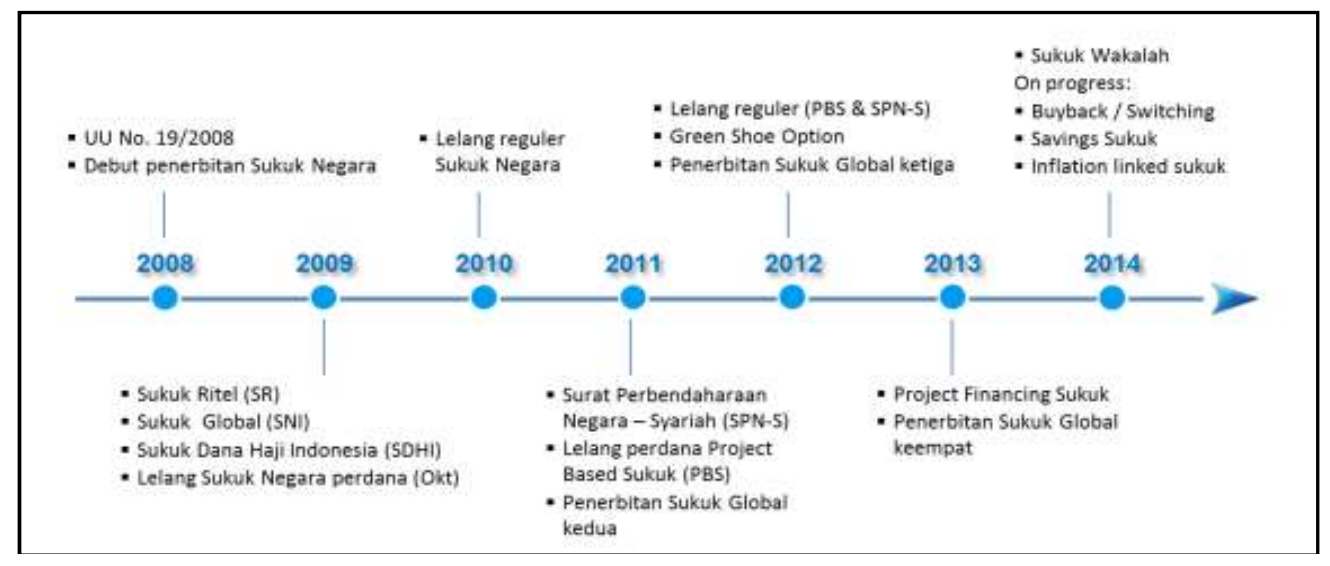

Gambar 2. Milestone Sukuk Negara 2008-2014 
Dengan disahkannya Undang-Undang Nomor 19 tahun 2008, pemerintah memiliki landasan hukum untuk dapat menerbitkan sukuk negara. Pada tanggal 26 Agustus 2008, Pemerintah Indonesia untuk pertama kalinya melakukan penerbitan Sukuk Negara di pasar perdana dalam negeri, yaitu Sukuk Negara seri Islamic Fixed Rate (IFR).

Penerbitan IFR seri IFR-0001 dan IFR-0002 dilakukan pertama kali pada tanggal 26 Agustus 2008, yang metode penjualannya dilakukan dengan menggunakan metode bookbuilding melalui 3 (tiga) Agen Penjual yang telah ditunjuk melalui seleksi oleh Pemerintah. Masa efektif bookbuilding relatif singkat, yakni empat hari kerja. Dari hasil penerbitan perdana tersebut terlihat tingginya minat dan kepercayaan pasar terhadap Sukuk Negara, yang tercermin dari kelebihan permintaan (over-subsricption) hingga 1,6 kali dengan total pemintaan mencapai Rp. 8,070 triliun dari target indikatif sebesar Rp. 5 trilliun. Porsi permintaan dari investor domestik cukup tinggi yakni kurang lebih Rp. 7,1 triliun atau $88 \%$ dari total permintaan (Pridityo, 2014). Hal ini menunjukkan bahwa sambutan investor domestik terhadap sukuk sebagai instrumen investasi di Indonesia cukup baik.

Tujuan utama pemerintah menerbitkan sukuk negara adalah untuk membiayai APBN, termasuk membiayai pembangunan proyek. Sebagaimana disebutkan pada pasal 4 UU SBSN bahwa tujuan diterbitkannya SBSN adalah untuk membiayai Anggaran Pendapatan dan Belanja Negara termasuk membiayai pembangunan proyek. Proyek yang dapat dibiayai dengan sukuk negara adalah sektor energi, telekomunikasi, perhubungan, pertanian, industri manufaktur, dan, perumahan. Adapun manfaat dari penerbitan sukuk ini antara lain adalah (Nur Kholis, 2010):

1) Memperluas basis sumber pembiayaan anggaran negara;

2) Memperkaya instrumen pembiayaan fiskal.

3) Memperluas dan mendiversifikasi basis investor SBN.

4) Mendorong pertumbuhan dan pengembangan pasar keuangan syariah di dalam negeri;

5) Mengembangkan alternatif instrumen investasi.

6) Menciptakan benchmark di pasar keuangan syariah.

7) Mengoptimalkan pemanfaatan Barang Milik Negara dan mendorong tertib administrasi pengelolaan Barang Milik Negara.

Departemen Keuangan sebagai pihak yang merepresentasikan pemerintah menegaskan bahwa dalam setiap penerbitan sukuk atau 
surat berharga syariah negara, tidak ada aset negara yang dijual atau digadaikan. Hal ini menjamin bahwa kepentingan investor dilindungi dalam investasi pada sukuk.

Pemerintah Indonesia mulai menerbitkan sukuk ritel mulai tahun 2009. Penerbitan sukuk ritel ini dilakukan untuk memperluas basis investor ritel sekaligus mengoptimalkan pasar dalam negeri. Sukuk Ritel merupakan surat berharga negara yang diterbitkan berdasarkan prinsip syariah sebagai bukti atas bagian penyertaan terhadap Aset SBSN, yang dijual kepada individu atau perseorangan warga negara Indonesia melalui agen penjual dengan volume minimum yang telah ditentukan. Sukuk ritel yang diterbitkan memberikan nilai strategis, karena dapat mendorong dan memfasilitasi mobilisasi dana masyarakat dalam rangka pembiayaan APBN. Pembiayaan dengan dana dari sukuk ini diharapkan secara bertahap dapat mengarah pada kemandirian bangsa dalam pembiayaan pembangunan. Penerbitan sukuk ritel juga diharapkan dapat mendorong pengembangan masyarakat pasar modal yang berakar kokoh di masyarakat (Pridityo, 2014).

Perkembangan selanjutnya dalam pemanfaatan sukuk sebagai instrumen pembiayaan adalah dengan penerbitan sukuk negara di pasar Internasional. Sebagai upaya untuk melakukan diversifikasi sumber pembiayaan APBN dan agar dapat berperan serta dalam pengembangan pasar keuangan syariah internasional, pada tahun 2009 pemerintah juga menerbitkan sukuk negara di pasar perdana internasional melalui penerbitan Sukuk Negara Indonesia (SNI). SNI tersebut diterbitkan dalam denominasi valuta asing di pasar perdana internasional dengan tingkat imbalan tetap dan dapat diperdagangkan. Sukuk internasional, yang biasa disebut dengan sukuk global pertama yang diterbitkan dengan format stand alone ini ternyata mendapatkan respon yang baik dari investor internasional. Hal ini terlihat dari volume penerbitan pada saat itu mencapai USD 650 juta, dan bookorder yang disampaikan melalui 3 joint lead managers mencapai USD 4,76 miliar. Jumlah volume penerbitan ini semakin menungkat dari tahun ke tahun hingga tahun 2014 lalu mencapai USD 1,5 Milyar.

\section{Pembahasan}

Upaya pemerintah dalam pengembangan instrumen sukuk terus dilakukan dengan melakukan pengelolaan Dana Haji dan Dana Abadi Umat dan agar dapat memberikan manfaat bagi pembiayaan APBN. Hal ini dituangkan dalam penandatangan Memorandum of Understanding 
(MoU) terkait penempatan dana haji dan Dana Abadi Umat ke dalam Sukuk Negara antara Kementrian Keuangan dan Kementrian Agama. Program penerbitan SDHI dengan cara private placement pertama kali dilaksanakan pada bulan Mei 2009, dan selanjutnya, penempatan dana haji dalam SBSN dilakukan secara periodik setiap tahun oleh Kementerian Agama.

Pada tahun 2011 Pemerintah juga melakukan mengembangkan instrumen Sukuk Negara jangka pendek di pasar domestik melalui penerbitan Surat Perbendaharaan Negara - Syariah (SPN-S). Instrumen ini diterbitkan untuk memenuhi kebutuhan arus kas jangka pendek Pemerintah sekaligus menyediakan instrumen likuiditas di pasar keuangan syariah. SPN-S merupakan Sukuk Negara jangka pendek (tenor 6 bulan) yang diterbitkan dalam rangka menutupi kekurangan kas jangka pendek akibat ketidaksesuaian antara arus kas penerimaan dan pengeluaran (cash mismatch) dari Rekening Kas Negara dalam satu tahun anggaran. Penerbitan SPN-S yang berjangka pendek ini juga disambut baik oleh para pelaku pasar karena selain dapat berfungsi sebagai instrumen pengelolaan cash mismatch, juga dapat digunakan untuk mendukung pelaksanaan operasi moneter oleh Bank Indonesia (market-based monetary policy).

Inovasi pemerintah dalam penerbitan sukuk terus berlangsung. Terkait dengan tujuan utama penerbitan sukuk, yaitu untuk membiayai pembangunan proyek, maka pemerintah mengembangkan instrumen Sukuk Negara yang dapat diterbitkan untuk tujuan pembiayaan proyek. Penerbitan Sukuk Negara untuk pembiayaan proyek dilakukan melalui penerbitan Project Based Sukuk (PBS). Sukuk Negara seri PBS merupakan Sukuk Negara yang diterbitkan dalam rangka pembiayaan proyek, baik dalam denominasi rupiah di pasar perdana dalam negeri, dengan tingkat imbalan tetap, serta dapat diperdagangkan di pasar sekunder.

Pada tanggal 11 Oktober 2011, pemerintah untuk pertama kalinya melelang sukuk negara berbasis proyek. Sukuk Negara PBS yang dilelang perdana adalah Sukuk Negara seri PBS-0001 dan seri PBS-0002. Sukuk jenis ini diterbitkan dalam rangka menjalankan amanat UndangUndang Nomor 19/2008 terutama terkait tujuan utama penerbitan Sukuk Negara yaitu untuk membiayai pembangunan proyek, Pemerintah mengembangkan instrumen Sukuk Negara yang dapat diterbitkan dalam rangka pembiayaan proyek. Hal ini sejalan dengan komitmen Pemerintah untuk turut serta berkontribusi bagi pembangunan infrastruktur. 
Pemerintah Indonesia kembali memasuki pasar keuangan syariah internasional pada awal September 2014 lalu, melalui penerbitan Sukuk Global senilai USD 1,5 Miliar. Penerbitan sukuk global ini adalah yang ke lima kali sejak tahun 2009. Penerbitan Sukuk Global juga dilakukan dalam rangka program pembiayaan APBN Tahun 2014, dan merupakan bagian dari strategi pembiayaan yang telah ditetapkan Pemerintah. Penerbitan Sukuk Global diharapkan juga dapat memberikan manfaat lain yaitu untuk lebih memperkuat posisi Indonesia di pasar keuangan syariah global serta untuk mendukung pengembangan keuangan syariah di dunia khususnya di kawasan Asia.

Pemerintah mulai melakukan program penerbitan Sukuk Global (Islamic GMTN) senilai total USD 3 Miliar, yang kemudian nilainya ditingkatkan menjadi total sebesar USD 5 Miliar. Penerbitan Sukuk Global di tahun 2014 ini adalah bagian dari Islamic GMTN Program dan merupakan penerbitan yang ketiga kalinya dilakukan di bawah Islamic GMTN tersebut. Setelah yang pertama pada tahun 2011 (USD 1 Miliar) dan kedua pada tahun 2013 (USD 1,5 Miliar).

Sukuk Global Pemerintah Indonesia diterbitkan melalui Perusahaan Penerbit SBSN Indonesia III. Yaitu badan hukum milik Pemerintah yang bertindak selaku Special Purpose Vehicle (SPV) dalam penerbitan Sukuk Negara. Sukuk Global senilai USD 1,5 Miliar tersebut ditetapkan dengan tingkat imbalan sebesar 4,35\% p.a, tenor 10 tahun dan akan jatuh tempo pada tahun 2024. Sukuk Global tersebut dicatatkan (listing) di Singapore Stock Exchange. Setelmen dilakukan pada tanggal 10 September 2014. ( http://www.djpu. kemenkeu.go.id/ index.php/page/loadViewer?idViewer $=4477$ \&action=download).

Sukuk Global Tahun 2014 berhasil memperoleh respon yang sangat positif dari para pelaku pasar internasional. Hal ini terlihat dari tingginya pemesanan pembelian (order book) yang mencapai lebih dari USD 10 Miliar dari sekitar 400 investor. Dengan kata lain, Sukuk Global Indonesia mengalami kelebihan permintaan (oversubscribed) hingga 6,82 kali lipat. Jumlah ini dapat dikatakan cukup fantastis dalam penerbitan sukuk internasional. Besarnya permintaan tersebut berimbas pada imbal hasil (yield) sukuk ke angka yang lebih rendah. Pada awalnya, Sukuk Global ditawarkan dengan yield sebesar 4,625\%. Namun pada akhirnya Pemerintah dapat menurunkan tingkat yield sebanyak 27,5 basis point hingga ke angka 4,35\%. Jauh lebih rendah dibandingkan tingkat yield Surat Utang Negara Konvensional sebesar 5,95\% yang diterbitkan pada 
bulan Januari 2014. Tingkat yield Sukuk Global tahun ini juga jauh lebih rendah dibandingkan tingkat yield Sukuk Global tahun sebelumnya yang mencapai sebesar $6,1 \%$. Hal tersebut menunjukan sentimen positif dari pelaku pasar terhadap Sukuk Global, yang dipengaruhi oleh kondisi pasar domestik Indonesia. (Pridityo, 2014).

Dari penerbitan tersebut Pemerintah selanjutnya melakukan alokasi investor. Dari sisi sebaran investor secara demografi, terlihat bahwa investor syariah dan Timur Tengah mendominasi jumlah investor Sukuk Global yaitu sebesar 35\%. Diikuti oleh investor Indonesia sebanyak 10\%, investor wilayah Asia selain Indonesia sebanyak 20\%, investor Amerika 20\%, dan investor Eropa sebanyak 15\%.

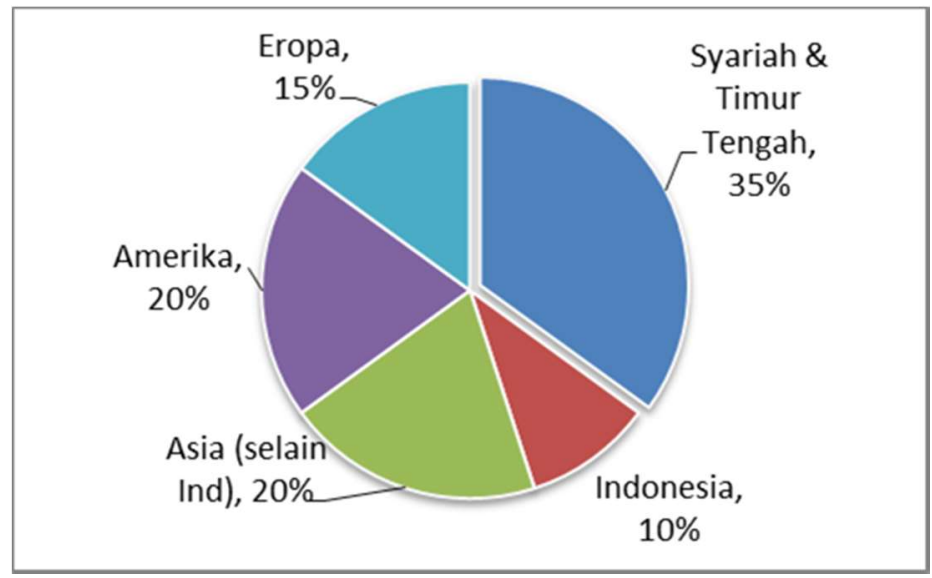

Gambar 3. Sebaran Investor Sukuk Global 2014 Berdasarkan Demografi)

Dominannya investor Timur Tengah dan Syariah dikarenakan Sukuk Global memang diarahkan untuk segmen pasar tersebut. (http:/ / investasi.kontan.co.id/news/negara-timteng-dan-islamdominasi-35-sukuk-global)

\section{Kesimpulan}

Sukuk merupakan salah satu instrumen keuangan syariah yang sedang berkembang pesat pertumbuhannya di dunia. Tidak hanya di negara-negara yang mayoritas penduduknya muslim, sukuk juga berkembang di berbagai negara di belahan dunia yang didominasi penduduk non muslim. Hal ini disebabkan sifat sukuk yang merupakan suatu instrumen investasi yang relatif aman. Pendapatan yang diperoleh dari sukuk ini berasal dari pemanfaatan dana yang tepat dan 
dijamin oleh aset yang riil (Nurkholis, 2011). Selain aman, sukuk juga telah nyata efektif digunakan sebagai instrumen pendanaan bagi berbagai kebutuhan keuangan negara baik yang bersifat jangka pendek maupun jangka panjang.

Sejak tahun 2008 sukuk mengambil peran yang cukup signifikan dalam pembangunan perekonomian Indonesia. Pada awal perkembangannya sukuk di Indonesia tergolong lambat, namun pengembangan terhadap sukuk terus menerus dilakukan oleh pemerintah. Pengembangan sukuk tersebut menyangkut varian sukuk, sumber dana sukuk, luasan pasar maupun sistem transaksi yang digunakan. Pengembangan yang dilakukan pemerintah terhadap sukuk ini ternyata mendapat sambutan yang cukup antusias baik dari pasar domestik maupun pasar global. Sukuk global yang diterbitkan oleh pemerintah Indonesia pada akhir 2014 bahkan mengalami kelebihan permintaan (oversubscribed), hingga mampu menurunkan tingkat yields (bagi hasil) yang harus diberikan kepada investor.

Sambutan yang besar terhadap sukuk Indonesia ini menjadi suatu alternatif yang sangat menjanjikan bagi pembiayaan berbagai proyek dan pembangunan yang berlangsung di Indonesia, mengingat cukup banyaknya keunggulan pembiayaan melalui sukuk dibandingkan utang negara berupa pinjaman luar negeri. Selain itu, sukuk juga dapat menjadi alternatif investasi yang halal bagi investor muslim maupun investor secara keseluruhan. Perkembangan sukuk ke depan diharapkan dapat semakin berperan besar dalam pembangunan perekonomian Indonesia. 


\section{DAFTAR PUSTAKA}

Abdul Wahid , Nazaruddin. 2010. Sukuk memahami \& membedah obligasi pada perbankan syariah S , Arruzz media

Bi Farmida, 2008. "AAOIFI Statement on Sukuk and It's Implications" Publication.

http://www.nortonrosefulbright.com/knowledge/publications/1 6852/aaoifi-statement-on-sukuk-and-its-implicationshttp:, diakses 10 Desember 2014

Eka Siskawati. (2010)Perkembangan Obligasi Syariah di Indonesia :

Suatu Tinjauan Jurnal Akuntansi \& Manajemen Vol .5 No.2

Desember 2010 ISSN 1858-3687 hal 1-9

http://www.aaoifi.com/en/standards-anddefinitions/shari\%E2\%80\%99a-standards/shari\%E2\%80\%99astandards.html, diakses 10 Desember 2014

Daniel, Wahyu. 2009. Tidak ada Aset Negara Yang Dijual Untuk Sukuk. http:/ / www.detikfinance.com/read/2009/07/01/094110/1156911 /5/depkeu-tidak-ada-aset-negara-yang-dijual-untuk-sukuk, diakses pada 9 Januari 2015

Depkeu. 2014. Pemerintah Republik Indonesia Menerbitkan Sukuk Global Senilai US 1,5 Milyar yang Akan Jatuh Tempo Pada Tahun 2024,

http://www.djpu.kemenkeu.go.id/index.php/page/loadViewer?i $\underline{\mathrm{d} \text { Viewer }=4477 \& \text { action }=\text { download }}$

Ismal, Rifki \& Khairunnisa Musari. (2009a). Sukuk Menjawab Resesi. Jurnal Ekonomia- Republika. 19 Maret.

Kharismawati, Margareta Engge. 2014. Negara Timteng dan Islam dominasi $35 \%$ sukuk global

,http://investasi.kontan.co.id/news/negara-timteng-dan-islamdominasi-35-sukuk-global) diunduh 5 Desember 2014

Mersilia, Elsi. 2014. Investasi Syariah: Perkembangan Obligasi Syariah di Indonesia, http:/ / elsimh-feb11.web.unair.ac.id/profil.html. Desember 2014

Nurkholis. 2010. Sukuk, Investasi Yang Halal dan Menjanjikan, Jurnal La Riba Vol 4 No 2

Pridityo, Anggoro (2014) Indonesia Kembali Menerbitkan Sukuk Global Senilai USD 1,5 Miliar.

https://anggoropridityo.wordpress.com/2014/09/03/indonesia- 
kembali-menerbitkan-sukuk-global-senilai-usd-15-miliar /

September 3, 2014

Pridityo, Anggoro (2014) Milestone Sukuk Negara 2008- 2014

https://anggoropridityo.wordpress.com/2014/10/04/milestone-

sukuk-negara-2008-2014, diakses 3 Januari 2015

Sunarsip (2008) . Prospek Sukuk di Indonesia . Harian Kontan , 26 Juni 2008

Zamir Iqbal and Abbas Mirakhor (2008). Pengantar Keuangan Islam:

Teori dan Praktik. Terjemahan. Edisi Pertama. Jakarta: Kencana, 224. 